\title{
Proteomic identification of moesin upon exposure to acrolein
}

\author{
Pureun-Haneul Lee ${ }^{1}$, Byeong-Gon Kim¹', Sun-Hye Lee ${ }^{1}$, George D. Leikauf ${ }^{2}$ and An-Soo Jang ${ }^{1 *}$
}

\begin{abstract}
Background: Acrolein (allyl Aldehyde) as one of smoke irritant exacerbates chronic airway diseases and increased in sputum of patients with asthma and chronic obstructive lung disease. But underlying mechanism remains unresolved. The aim of study was to identify protein expression in human lung microvascular endothelial cells (HMVEC-L) exposed to acrolein.

Methods: A proteomic approach was used to determine the different expression of proteins at $8 \mathrm{~h}$ and $24 \mathrm{~h}$ after treatment of acrolein $30 \mathrm{nM}$ and $300 \mathrm{nM}$ to HMVEC-L. Treatment of HMVEC-L with acrolein $30 \mathrm{nM}$ and $300 \mathrm{nM}$ altered 21 protein spots on the two-dimensional gel, and these were then analyzed by MALDI-TOF MS.

Results: These proteins included antioxidant, signal transduction, cytoskeleton, protein transduction, catalytic reduction. The proteins were classified into four groups according to the time course of their expression patterns such as continually increasing, transient increasing, transient decreasing, and continually decreasing. For validation immunohistochemical staining and Western blotting was performed on lung tissues from acrolein exposed mice. Moesin was expressed in endothelium, epithelium, and inflammatory cells and increased in lung tissues of acrolein exposed mice compared with sham treated mice.
\end{abstract}

Conclusions: These results indicate that some of proteins may be an important role for airway disease exacerbation caused by acrolein exposure.

Keywords: Acrolein, Asthma, HMVEC-L, Moesin, Proteomics

\section{Background}

Smoking is a major risk factor for morbidity and mortality worldwide [1]. Cigarette smoking and asthma are associated with poor symptom control and impaired therapeutic responses to antiasthma drugs $[2,3]$. Compared with asthmatic nonsmokers, smokers with asthma have worse symptom control [4], an accelerated decline in lung function [5], and an increased mortality rate [6]. Steroid treatment and smoking cessation can improve symptom and lung function of asthma [7, 8]. Increased number, size and density of blood vessels, as well as vascular leakage and plasma engorgement, have been reported in the airways of patients with all grades of asthma from mild to fatal [9].

\footnotetext{
* Correspondence: jas877@schmc.ac.kr

${ }^{1}$ Division of Allergy and Respiratory Medicine, Department of Internal Medicine, Soonchunhyang University Bucheon Hospital, 170 Jomaru-ro, Wonmi-gu, Bucheon, Gyeonggi-do 420-767, South Korea

Full list of author information is available at the end of the article
}

Angiogenesis relies on the proliferation and migration of endothelial cells [10]. The importance of endothelial cell proliferation for expansive growth of the vascular network has long been recognized [11]. The endothelium is a monolayer of cells lining the interior of the blood and lymphatic vessels. This cellular layer is attached to the basal membrane and participates in the exchange of materials between blood and tissues. Endothelial cells have essential activities in the control of vascular functions and play an important role in the formation of new blood vessels and restoration of damaged vessels $[12,13]$. Endothelial cells release a multitude of biological mediators such as growth factors, vasoactive mediators, coagulation and fibrinolysis proteins, and immune factors. These cells are usually in the quiescent state, reflecting the stability and integrity of the vascular wall [14-18].

Acrolein (2-propenal) is an $\alpha, \beta$-unsaturated aldehyde that is volatile at room temperature and is highly 
irritating to eyes and respiratory passages [19]. Acrolein can be formed by heating cooking oils and fats above $300{ }^{\circ} \mathrm{C}$ [20], and can be formed in domestic cooking with biomass fuels [21], and is present in environmental tobacco smoke [19, 22], which remains a significant occupational health hazard in the restaurant workplace $[23,24]$. Acrolein levels were higher in induced sputum and in exhaled breath condensate in both asthma and COPD [25]. Acrolein induces changes in a diverse range of proteins that may be related to cellular toxicity in rat lung epithelial cells and that toxic effects of acrolein may be due to deregulation of proteins involved in proliferation and apoptosis [26], and has the potential to modify a wide variety of cysteine-containing proteins within airway epithelial cells [27].

By proteomic approach, we have been able to address whether timing and dose exposures of acrolein influence endothelial protein expression. Two dimentional electroporesis data was validated in acrolein exposed mice.

\section{Methods}

\section{Cell culture and stimulation with Acrolein}

Primary human lung micro vascular endothelial (HMVEC-L) cells (Lonza, Switzerland) (5000cells $/ \mathrm{cm}^{2}$ ) were grown in $\mathrm{EGM}^{\mathrm{m}}-2 \mathrm{MV}$ BulletKit ${ }^{\mathrm{mm}}$ (Lonza, Basel, Switzerland). The medium was replaced every $48 \mathrm{~h}$ until cells reached $90 \%$ confluence at $37{ }^{\circ} \mathrm{C}$ under $5 \% \mathrm{CO}_{2}$. The cells are seeding in $150 \mathrm{~cm}^{2}$ plate. For experimental treatment, HMVEC-L were re-cultured in $\mathrm{EGM}^{\mathrm{Tm}}-2 \mathrm{MV}$ with $0.1 \%$ FBS for $30 \mathrm{~min}$, and Treatment of the various concentrations of Acrolein cultured at $37{ }^{\circ} \mathrm{C}$ under $5 \%$ $\mathrm{CO} 2$ incubator for $8 \mathrm{~h}$ and $24 \mathrm{~h}$.

Two-dimensional (2-D) electrophoresis and image analysis HMVEC-L cells were harvested by centrifugation and then disrupted with lysis buffer containing $5 \mathrm{mM}$ Tris- $\mathrm{HCl}$ (pH 7.4), $100 \mathrm{mM} \mathrm{NaCl}, 1 \%$ Triton X-100, and $2 \mathrm{mM}$ PMSF. The cell lysate was centrifuged at 12,000 X $g$ for $30 \mathrm{~min}$, and the supernatant fraction was collected. Protein concentrations were determined using a BCA assay kit (Pierce). Immobiline DryStrips (Amersham Biosciences) were used for isoelectric focusing, which was carried out with $1 \mathrm{mg}$ of the extracted protein on an IPGphor system (Amersham Biosciences). After IEF separation, the proteins were separated in the second dimension by SDS-PAGE. For image analysis, the gels were visualized with Coomassie Brilliant Blue G-250 according to the manufacturer's instructions. The 2-D gels were scanned with an ImageScanner (Amersham Biosciences) in transmission mode. Spot detection and matching were performed using ImageMaster 2D version 5.0 (Amersham Biosciences). Digitized images were analyzed using the ImageMaster program to calculate the 2-D spot intensity by integrating the optical density over the spot area (the spot "volume") and normalized. The values were normalized and then exported to SPSS 18.0 for statistical analysis.

\section{Protein identification by MALDI-TOF MS analysis and database searching}

Mass spectrometry (MS) was performed at the Yonsei Proteome Research Center (YPRC, Korea). Peptides obtained after trypsin digestion from cell lysate were analyzed with a MALDI-TOF/TOF mass spectrometer (4800 ABSciex, USA). For sample preparation, 70\% ACN was allowed to flow through the porous tip to remove impurities attached to the resin. Next, a solution of $2 \%$ formaldehyde was passed through the column to create acidic conditions. Following this pretreatment, the samples to be analyzed were passed through the column. Subsequently, the wash buffer (2\% FA) was used to remove impurities such as salt and chemicals. Finally, the peptides attached to the resin were elute.

\section{Database search and protein identification}

MS and MS/MS data were used in subsequent searches by Mascot software (Matrix Science; http://www.matrix science.com) using the MSDB protein sequence database for human proteins.

\section{Acrolein exposure and histology examination}

This study was performed in accordance with the Institutional Animal Care and Use Committee of the Soonchunhang University Bucheon Hospital and mice were housed under specific pathogen free conditions. 6to 8-week-old BALB/c female mice $(n=8$ mice; Orient Bio, Sungnam, Korea) were used in the study. Animals were exposed to filtered air (control) or Ovalbumin $(3 \mu \mathrm{g} / \mathrm{ul})$ or acrolein $(5 \mathrm{ppm}, 6 \mathrm{~h})$ generated and monitored as described previously [28].

To examine acrolein-induced changes in lung histology, Mice were anesthetized by intraperitoneal injection of with $2.5 \mathrm{mg} / \mathrm{kg}$ tiletamine and xylazine (Zoletil and lumpum; Bayer Korea Co., Seoul, Korea). The following day BALF was obtained, centrifuged, and the supernatant stored $\left(-20{ }^{\circ} \mathrm{C}\right)$. The cell pellet was resuspended for cell count and cytospin slides were made for cell differential (500 cells/mouse, Diff-Quickstaining). A portion of the lung was fixed in $4 \%$ phosphate-buffered paraformaldehyde, embedded in paraffin, sectioned, and stained.

Fixed lungs were washed with Dulbecco's PhosphateBuffered Saline containing Ca2+, Mg2+, $6.1 \mathrm{mM}$ D-glucose, and $0.33 \mathrm{mM}$ sodium pyruvate (DPBS; Cat. No. 14287-080, Life Technologies, Carlsbad, CA), dehydrated through a series of graded ethanol solutions (30-70\%), and processed in paraffin blocks (Hypercenter $\mathrm{XP}$, Shandon, Ramsey, MN). The lung tissue was 
sectioned $(4 \mu \mathrm{m})$ and stained with hematoxylin and eosin. Total protein in cell-free supernatants was measured using a bicinchoninic acid assay (BCA; Thermo Scientific, USA) using bovine serum albumin as a standard.

\section{Determination of airway responsiveness to methacholine} Airway responsiveness was measured in unrestrained, conscious mice 1 day after the last challenge, as described previously [29]. Mice were placed in a barometric plethysmographic chamber (All Medicus Co, Anyang, Korea) and baseline readings were taken and averaged for $3 \mathrm{~min}$. Increasing concentrations of aerosolized methacholine, from 0 to $100 \mathrm{mg} / \mathrm{mL}$, were nebulized through an inlet of the main chamber for $3 \mathrm{~min}$. Readings were taken and averaged for $3 \mathrm{~min}$ after each nebulization, and the enhanced pause (Penh) was determined. Penh, calculated as (expiratory time/relaxation time-1) X (peak expiratory flow/peak inspiratory flow), is a dimensionless value that represents a function of the proportion of maximal expiratory to maximal inspiratory box pressure signals and is a function of the timing of expiration. Penh was used as a measure of airway responsiveness to methacholine. Results were expressed as the percentage increase in Penh following challenge with each concentration of methacholine, where the baseline Penh (after saline challenge) was expressed as an actual value. Penh values averaged for $3 \mathrm{~min}$ after each nebulization were evaluated.

\section{Western blot analysis of Moesin expression}

The extracted lung tissues were homogenized in a protein lysis solution containing $50 \mathrm{mM}$ Tris-HCL (pH 7.4), $50 \mathrm{mM} \mathrm{NaCl}, 0.1 \%$ SDS, 1\% Triton X-100, $0.5 \mathrm{mM}$ EDTA, and $100 \mathrm{mM}$ PMSF in distilled water, and centrifuged at $14000 \mathrm{rpm}$ for $30 \mathrm{~min}$ at $4{ }^{\circ} \mathrm{C}$, and the insoluble materials were collected. Proteins were fractionated by $10 \%$ SDS-PAGE and transferred to a PVDF membrane (millipore). The membrane was blocked for $1 \mathrm{~h}$ in TBS containing 5\% BSA and then incubated with polyclonal rabbit anti-Moesin antibody (1:1000 dilution) at $4{ }^{\circ} \mathrm{C}$ overnight. The unbound primary antibodies were removed with three 10-min washes in TBS containing 0.01 Tween-20. The membrane was then incubated with goat anti-rabbit for $1 \mathrm{~h}$. ECL detection of moesin was performed according to the manufacturer's instructions (Roche Applied Science).

\section{Analysis of Moesin expression in lung tissue of Acrolein exposured mouse by Immunohistochemical staining}

Mouse lung sections were deparaffinizied and rehydrated in an ethanol series to examine the secretion of Moesin. Four-micrometer tissue section slides were treated with $0.3 \% \mathrm{H}_{2} \mathrm{O}_{2}$-methanol for $30 \mathrm{~min}$ to block endogenous peroxidase and then incubated with Moesin antibody (1:100 dilution, abcam) at $4{ }^{\circ} \mathrm{C}$ overnight. After washing with Tris-buffered saline the slides were incubated with avidin-biotin peroxidase complex (ABC kit, Vector Laboratory, Burlingame, CA). Color reaction was developed by staining with liquid $\mathrm{DAB}+$ substrate kit (Golden Bridge International Inc., Mukilteo, WA). After immunohistochemical staining the slides were counterstaining the slide with Herris's hematoxylin for $1 \mathrm{~min}$.

\section{Statistical analysis}

Statistical analysis was performed using SPSS 18.0 software. Differences in spot intensity on 2-D gels were multiple compared between three independent groups or samples using the non-parametric Kruskal-Wallis $H$ test for continuous data. If differences were found significant, the Mann-Whitney $U$ test (two-sample rank sum test) was applied to the differences in densities and concentrations of the groups. All data were expressed as median values (interquartile range), and significance was defined as $p<0.05$.

\section{Results}

\section{2-D electrophoresis and protein identification}

A proteomics approach was used to determine the differential expression of proteins at 8 and $24 \mathrm{~h}$ after treatment of HMVEC-L cells with $30 \mathrm{nM}$ and $300 \mathrm{nM}$ acrolein. Protein fraction were obtained by differential centrifugation and then separated by 2-D electrophoresis in six replicate gels per treatment. A representative image of the proteomic profile of HMVEC-L cells prior to treatment is shown in Figs. 1 and 2. A total of 427 (median, 425; range, 400-460) protein spots were detected on each gel. All of the identified spots were localized in the pI3-10 range with a molecular mass range of $10-200 \mathrm{kDa}$. This 2-D gel image was used as a master gel and reference map. 2-D PAGE of extracts from acrolein-treated cells revealed 11 spots for $30 \mathrm{nM}$ and 10 spots for $300 \mathrm{nM}$ that changed by more than 3 -fold at 8 or $24 \mathrm{~h}$ after treatment. These spots were excised from the gel and incubated with trypsin to digest the proteins in the gel, which were then analyzed by MALDI-TOF MS. The results of this analysis are summarized in Table 1, 2, 3 and 4.

\section{Cluster analysis}

The expression profiles of the 21 proteins with significant $(p<0.05)$ differential expression were visualized using a hierarchical clustering algorithm. Four fundamental profile patterns could be identified from the clusters: transiently increasing (Figs. 3 and 4, Group A), continuously increasing (Figs. 3 and 4, Group B), 

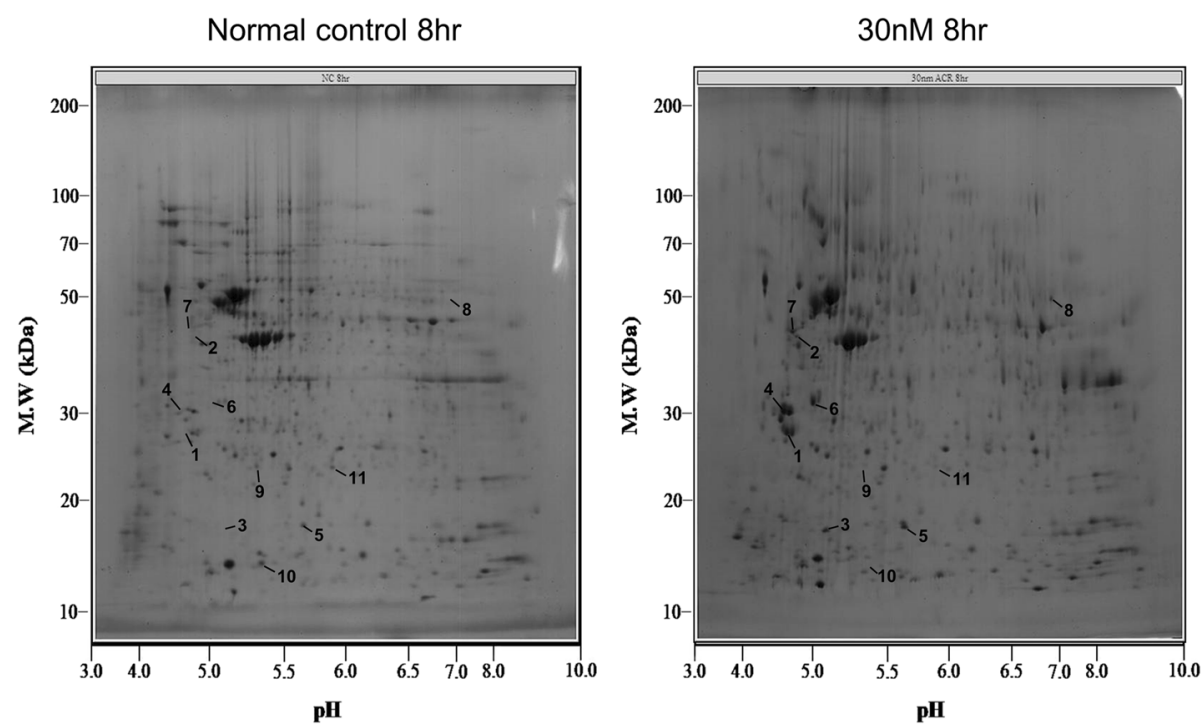

Fig. 1 Two-dimensional electrophoresis of human lung microvascular endothelial cells. The 2-D PAGE image from lysates of untreated cells was used as a master gel and reference map. Acrolein $30 \mathrm{~nm}$ treatment caused 11 spots to change by more than 3 -fold at 8 or $24 \mathrm{~h}$. Protein spots identified by MALDI-TOF MS (arrow) are marked by their spot numbers

transiently decreasing (Figs. 3 and 4, Group C), and continuously decreasing (Figs. 3 and 4, Group 4).

Treatment of human lung microvascular endothelial cells (HMVEC-L) with acrolein $30 \mathrm{nM}$ altered 11 protein spots on the two-dimensional gel, and these were then analyzed by MALDI-TOF MS. These proteins included antioxidant, signal transduction, cytoskeleton, protein transduction, catalytic reduction.
The proteins were classified into four groups according to the time course of their expression patterns such as continually increasing, transient increasing, transient decreasing, and continually decreasing. The proteins in each group are summarized in Table 1, 2, 3 and 4. The Adenylyl cyclase-associated protein (CAP), Annexin A5 (ANXA5), 14-3-3 protein epsilon isoform (YWHAE), phospholipase A2 (PLA2), initiation factor 4D (eIF-4D)
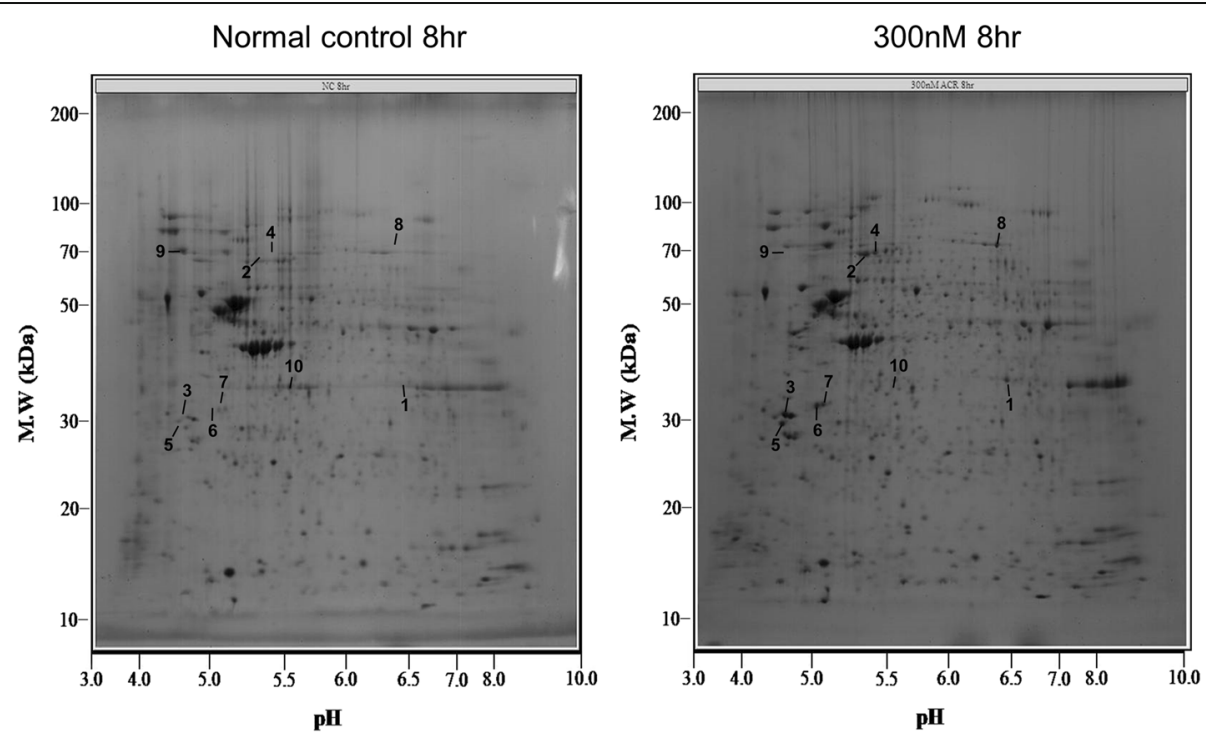

Fig. 2 Two-dimensional electrophoresis of human lung microvascular endothelial cells.The 2-D PAGE image from lysates of untreated cells was used as a master gel and reference map. Acrolein $300 \mathrm{~nm}$ treatment caused 10 spots to change by more than 3-fold at 8 or 24 h. Protein spots identified by MALDI-TOF MS (arrow) are marked by their spot numbers 


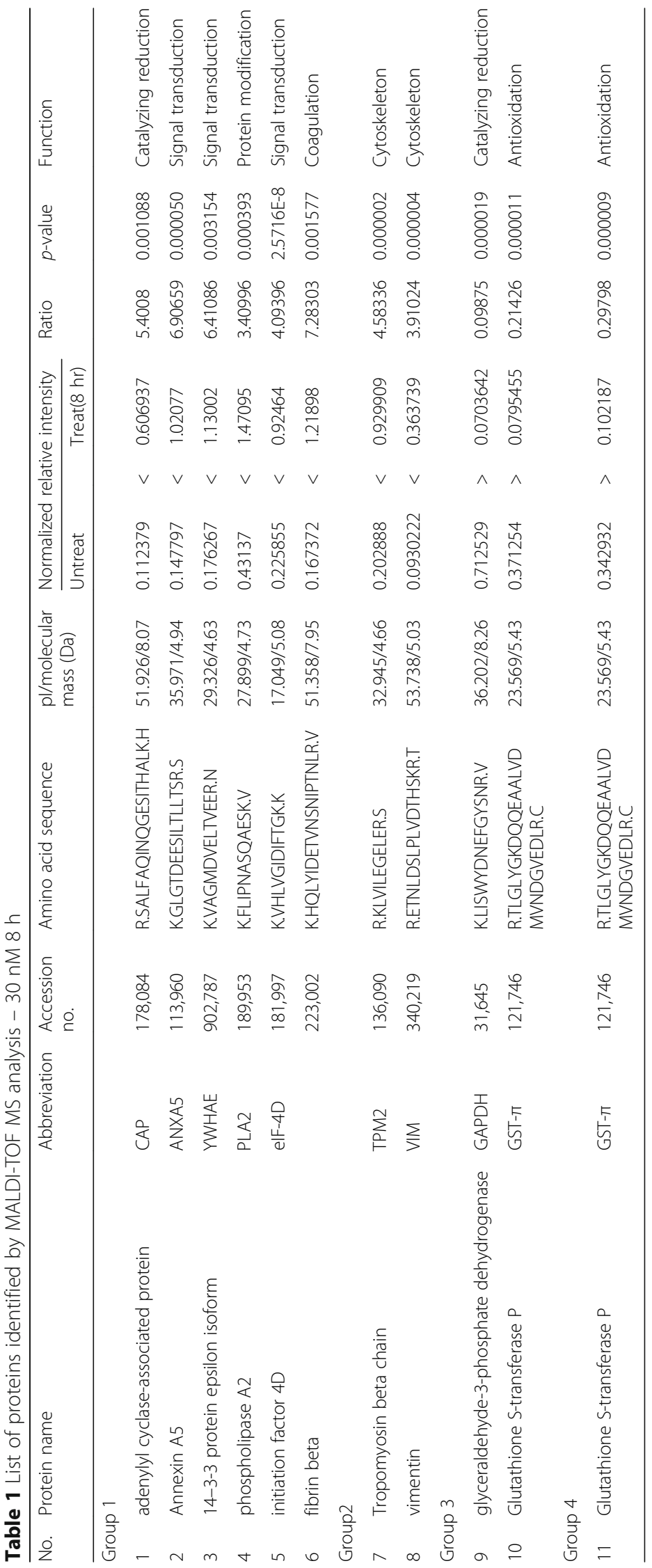




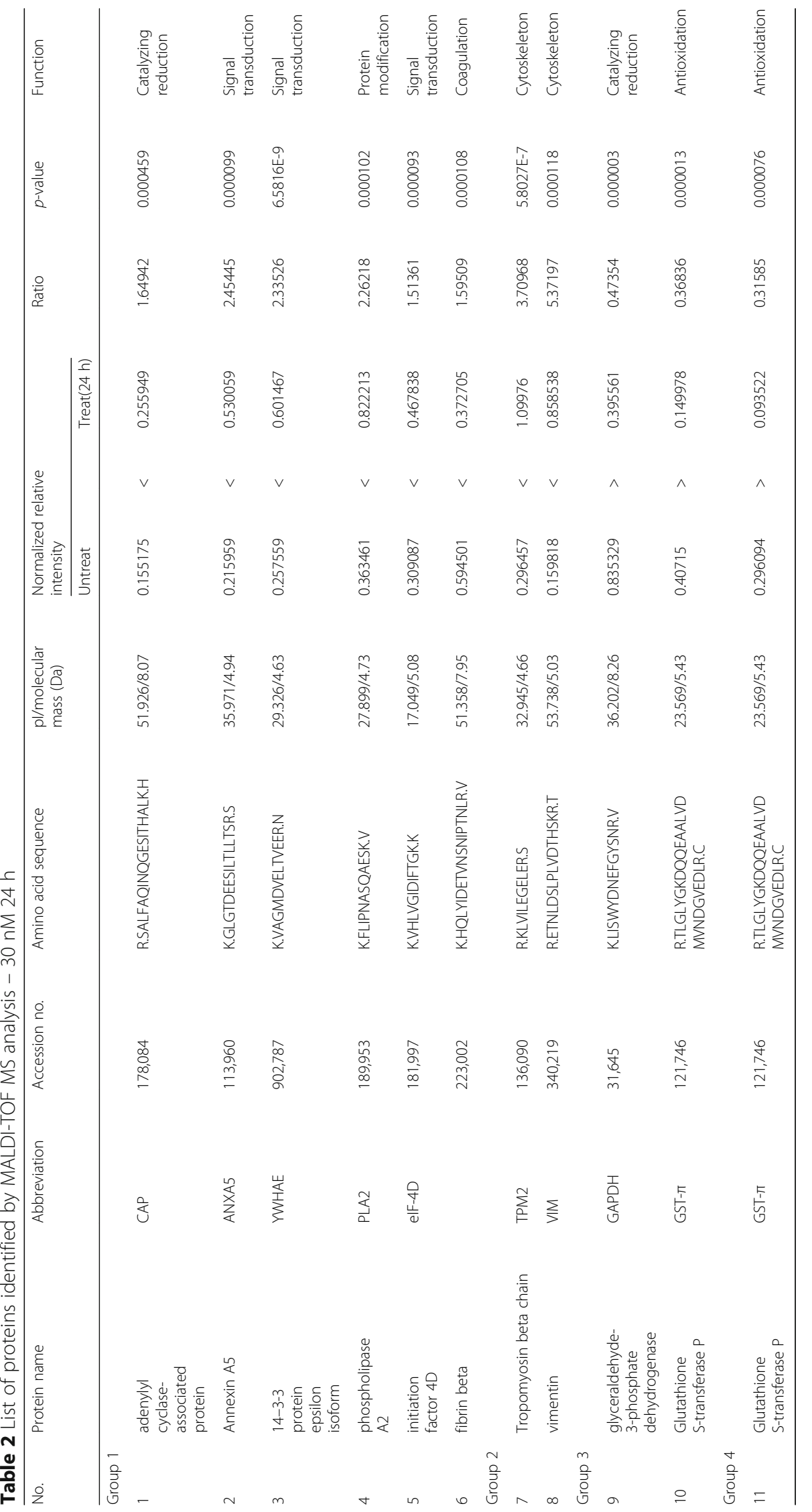




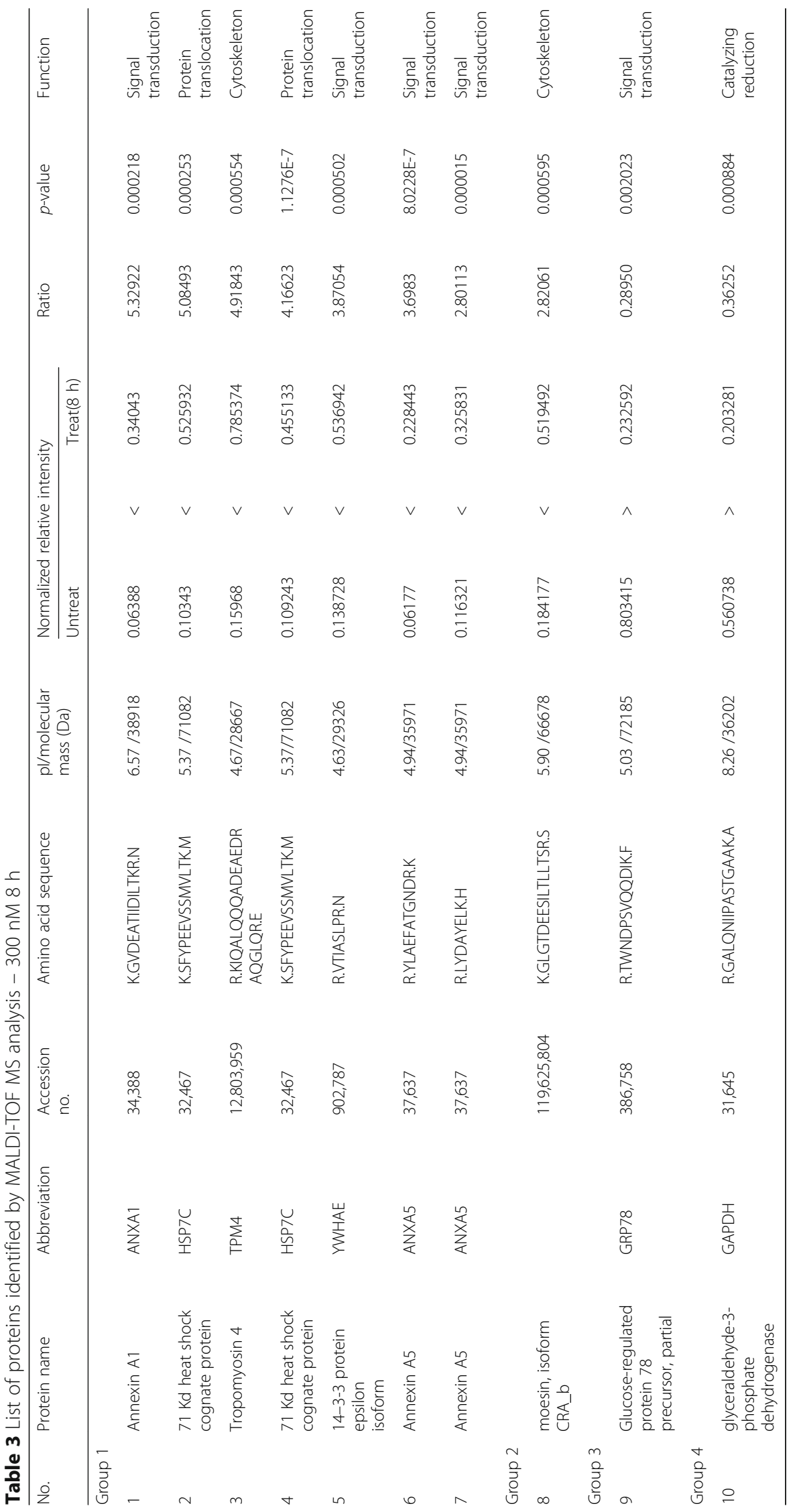




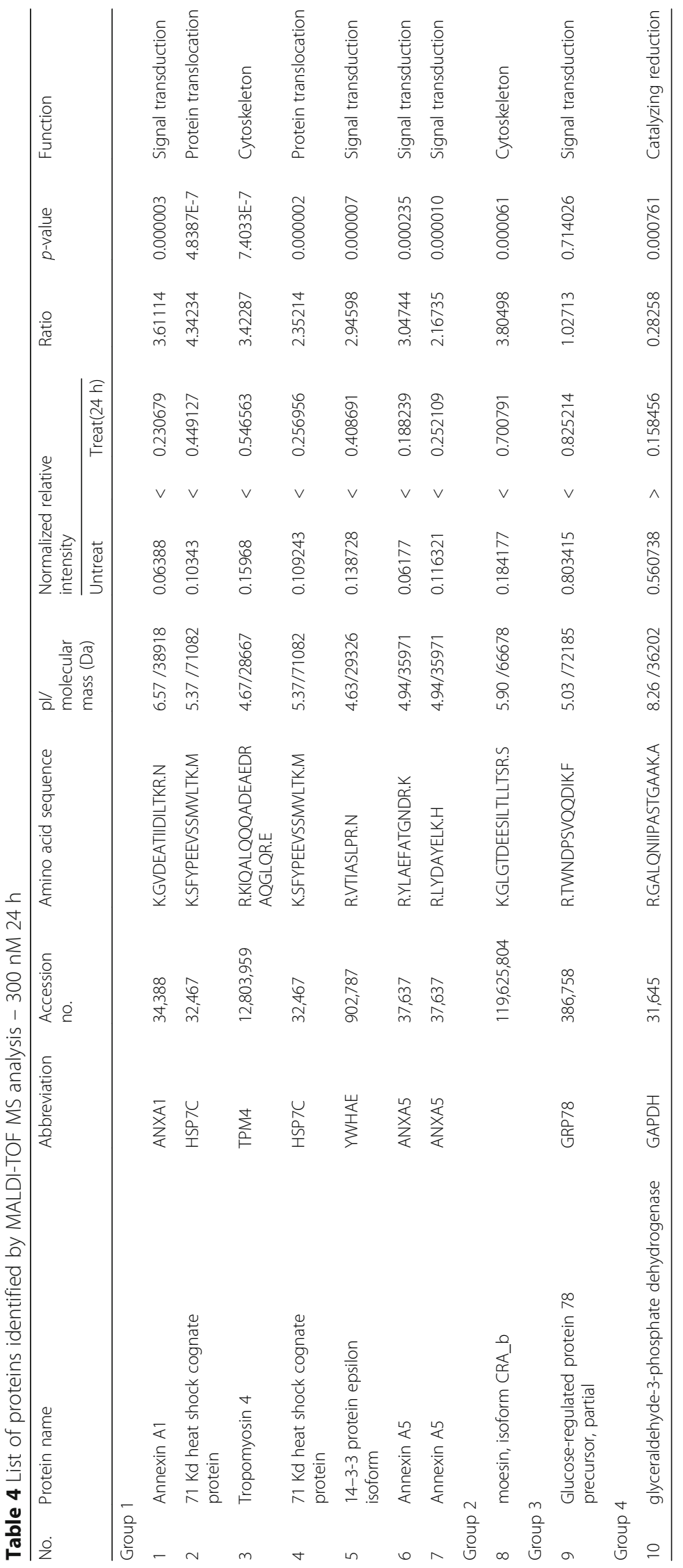



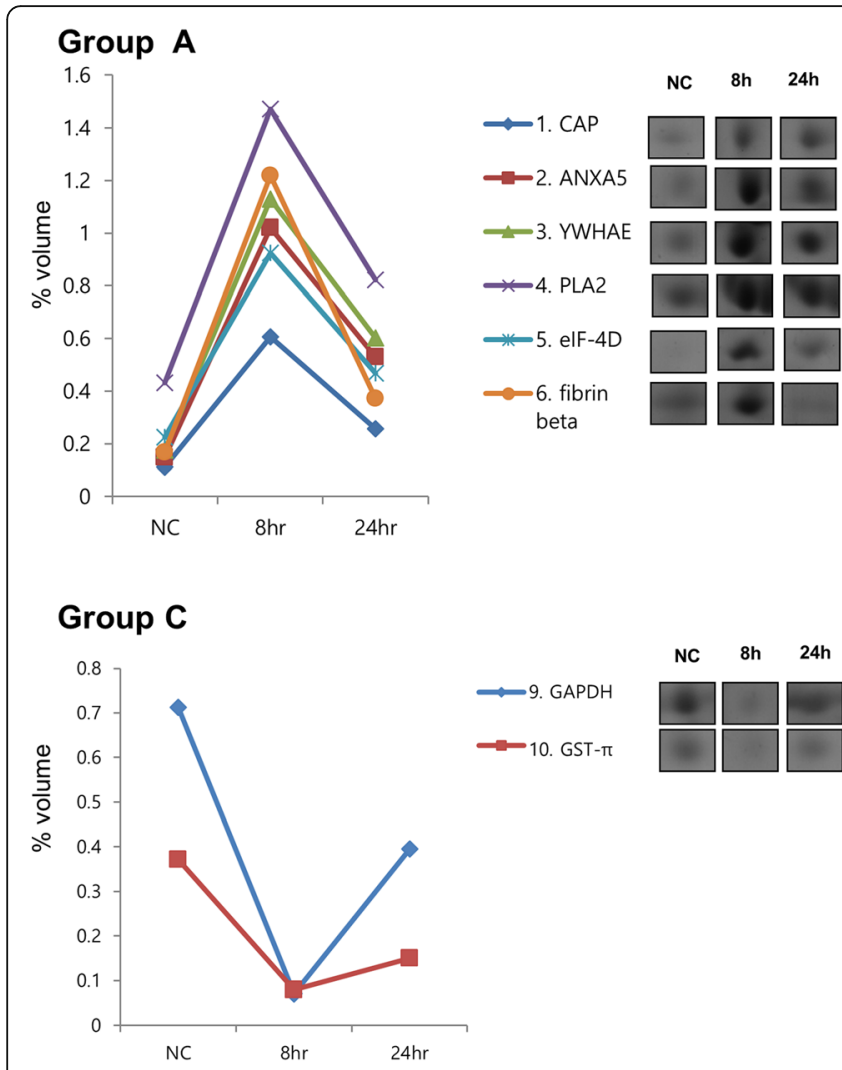

\section{Group B}

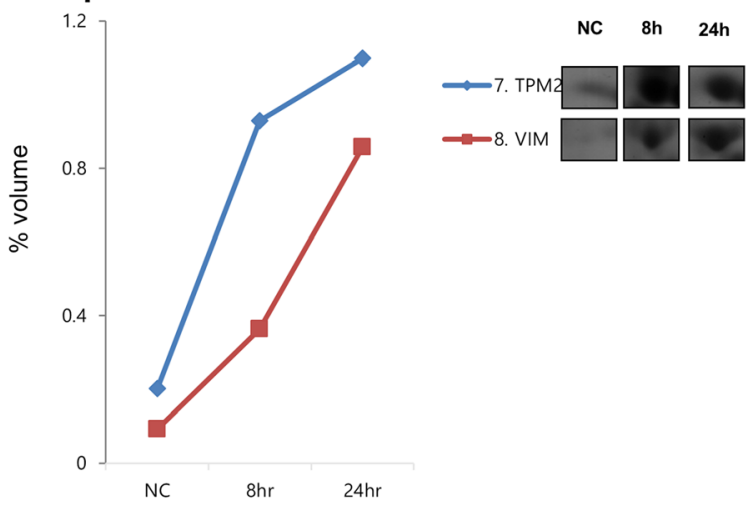

Group D

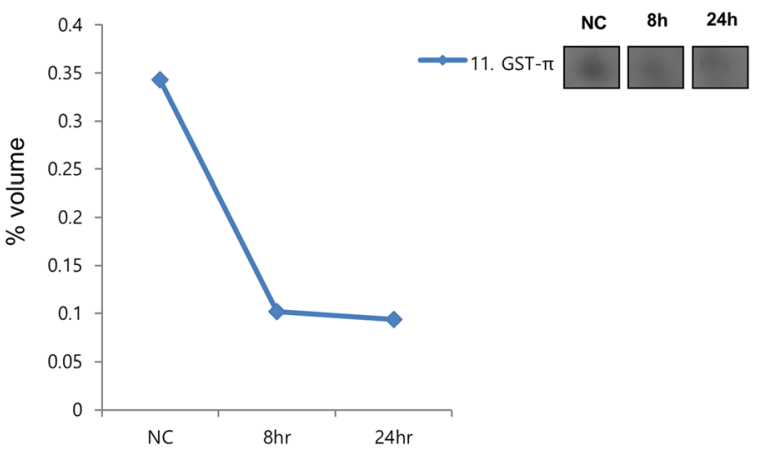

Fig. 3 Cluster analysis of 11 proteins with significant differential expression (>3-fold change) at 8 or 24 h caused by 30 nm acrolein treatment of human lung microvascular endothelial cells. The expression profiles of the individual proteins were classfied by cluster analysis. Protein names National Center for Biotechnology Information (NCBI) are displayed for each cluster

and fibrin beta were included in group A. The Tropomyosin beta chain (TPM2) and Vimentin (VIM) were in group B.

A continuous decrease in Glutathione S-transferase P (GST- $\pi$ ) was observed in group C. A transient decrease in glyceraldehydes-3-phosphate dehydrogenase (GAPDH) and Glutathione S-transferase P (GST- $\pi$ ) was observed in group D.

Treatment of HMVEC-L with acrolein $300 \mathrm{nM}$ altered 10 protein spots on the 2-D, and these were then analyzed by MALDI-TOF MS. These proteins included signal transduction, cytoskeleton, protein transduction, catalytic reduction. The proteins were classified into four groups according to the time course of their expression patterns such as continually increasing, transient increasing, transient decreasing, and continually decreasing. The Annexin A1 (ANXA1), $71 \mathrm{Kd}$ heat shock cognate protein (HSP7C), Tropomyosin 4 (TPM4), 71Kd heat shock cognate protein (HSP7C), 14-3-3 protein epsilon isoform (YWHAE), Annexin A5 (ANXA5) were included in group A. The Moesin, isoform CRA_b was in group B. A continuous decrease in glyceraldehydes-3phosphate dehydrogenase (GAPDH) was observed in group
C. A transient decrease in Glucose-regulated protein 78 precursor, partial (GRP78) was observed in group D.

\section{Identification of Moesin-expressing HMVEC-L in acrolein- treated mice lung}

To determine whether Moesin and the other proteins expression in lung tissue is elevated after in vivo stimulation with acrolein, we exposed ovalbumin $(3 \mu \mathrm{g} / \mathrm{ul})$ for 3 days or acrolein in mice for 5 ppm for 3 days. The acrolein-exposed mice group exhibited a greater increase in Penh compared to sham mice group (Fig. 5b). Examination of the BALF showed increased total and differential cell counts in the acrolein-exposed mice group compared to cell counts in the sham mice group (Fig. 5c). Expression of Moesin protein in intrapulmonary bronchi was examined by immunohistochemical staining. After acrolein $5 \mathrm{ppm}$ exposure for 3 days, Western blot analysis of homogenates from sham- and acrolein-exposed mice lung lysates $(20 \mu \mathrm{g}$ of protein/ lane) showed that Moesin protein significantly increased in lung from acrolein- treated mice compared with that from untreated mice (Fig. 5d). Moesin was detected in the endothelial cell, epithelial cells of the bronchi and 


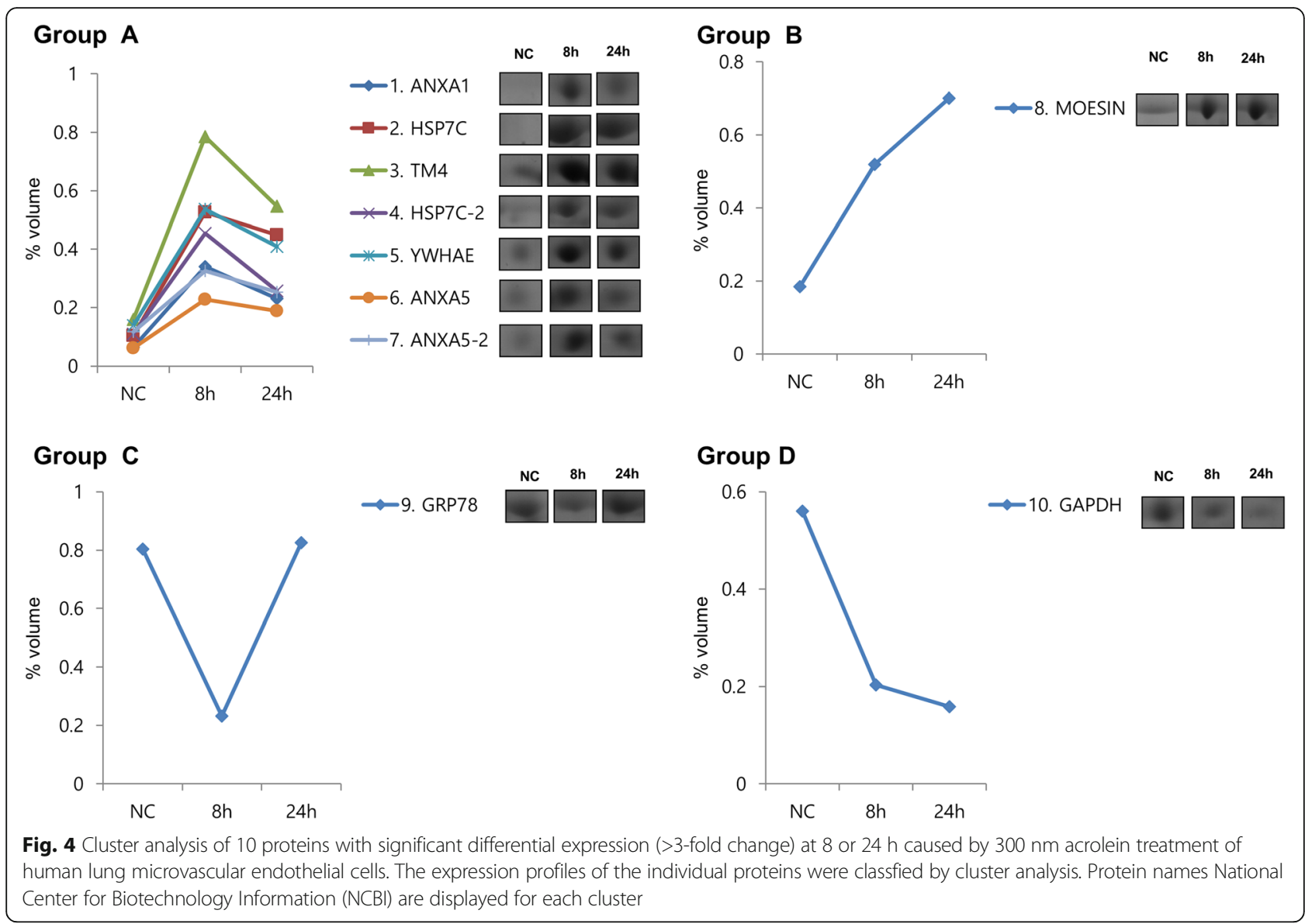

bronchioles, and inflammatory cells (Fig. 5e). In addition, Those results for the other two biological replicates revealed that the acrolein-exposed mice group and the acrolein-OVA exposed mice group significantly increased two proteins (Annexin A1 and Tropomyosin 2) compared to sham mice group (see Additional file 1).

\section{Discussion}

Respiratory diseases are increasing cause of morbidity and mortality for all age groups and races in the changing global environment [30]. Despite differences in the causal agents, both asthma and chronic obstructive lung disease (COPD) exhibit various degrees of inflammatory changes, airway narrowing leading to airflow limitation and structural alterations of the pulmonary airways and vessels [31-33].

The involvement of residential cells such as endothelial cells, airway smooth muscle cells (ASM) and pulmonary fibroblasts, all appear to have a crucial role in the progression of vascular inflammation and remodeling $[30,34]$. The density of vessels in the medium $(2-5 \mathrm{~mm}$ inner diameter) and small $(<2 \mathrm{~mm})$ airways is significantly elevated in mild and moderate-to-severe asthma compared to healthy controls or subjects with COPD [32] and has been linked to asthma severity [35,
36]. Ongoing inflammatory processes in asthma may result in structural changes in the pulmonary vasculature and contribute to an influx of progenitors and increased synthesis of vascular mediators [30]. However, more studies are warranted to increase the knowledge of the cells and mediators associated with the vascular changes involved in the development of airway obstruction and remodeling processes in asthma [30].

Acrolein is a respiratory irritant that can be generated during cooking and is in environmental tobacco smoke $[19,37-40]$. Acrolein is also generated endogenously at sites of injury, and excessive breath levels and induced sputum have been detected in asthma and COPD [19, $25,41]$. Because of its reactivity with respiratory-lining fluid or cellular macromolecules, acrolein alters gene regulation, inflammation, mucociliary transport, and alveolar-capillary barrier integrity [19].

Therefore in this study we have examined the effect of acrolein on human lung vascular endothelial cells and lungs of mouse model of asthma. Our data revealed four patterns of protein expression groups according to the time course of their expression patterns such as continually increasing, transient increasing, transient decreasing, and continually decreasing. 


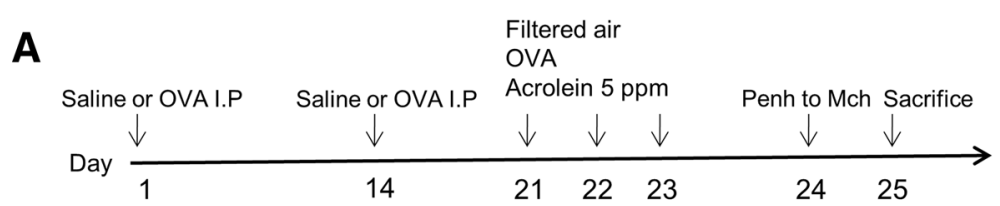

B

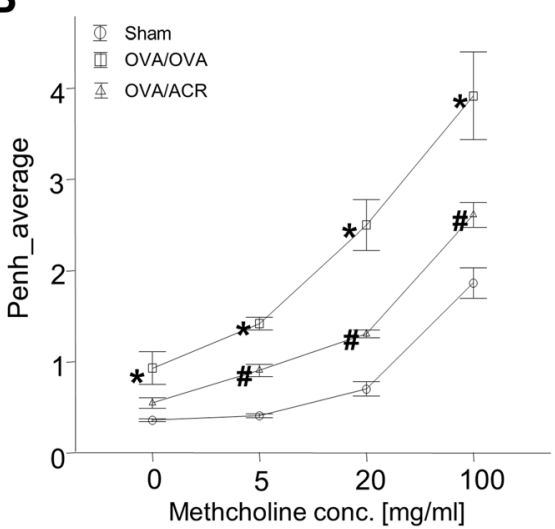

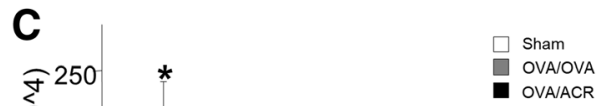

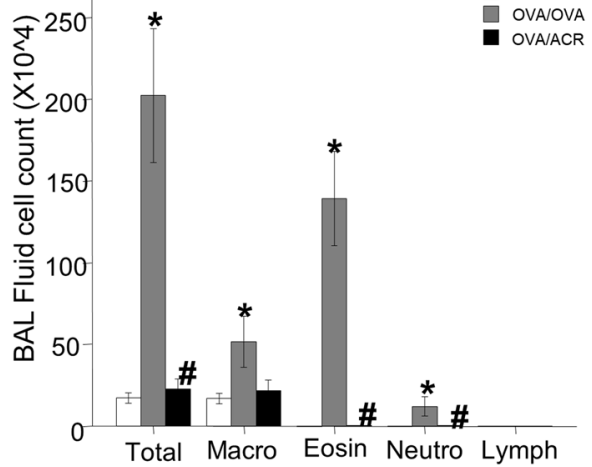

D

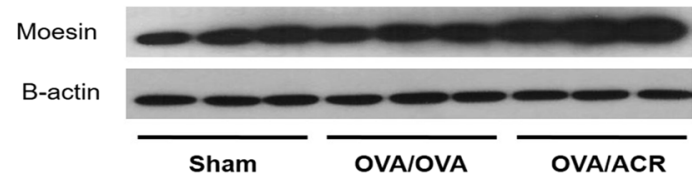

E

Sham

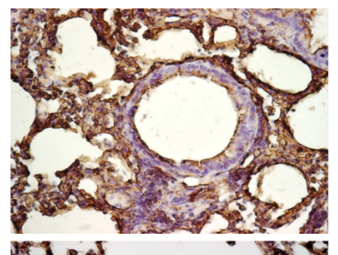

Vessel

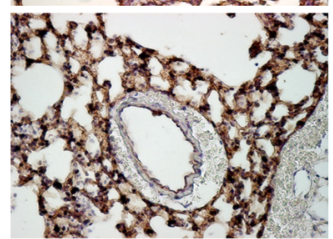

OVA/OVA

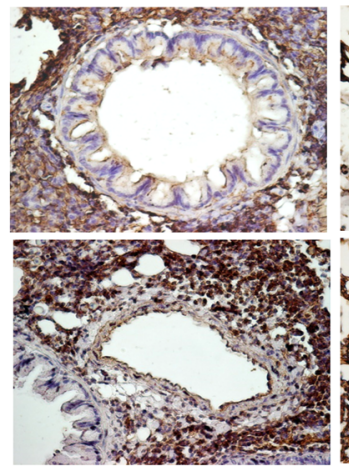

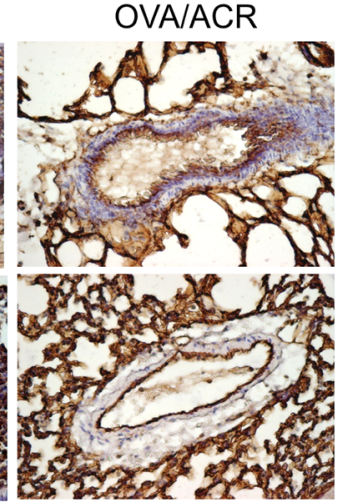

Fig. 5 Experiment protocol of asthma model and expression of Moesin in lung tissue of acrolein-treated and sham-treated mice. a. OVAVOVA were sensitized intraperitoneal injection (I.P) at day 0, 14 to BALB/C. All mice received intranasal treatment (I.N) at day 21 to 23 with or without acrolein $1 \mathrm{~h}$ before OVA challenge. $\mathbf{b}$ and $\mathbf{c}$. acrolein-treated mice increased cell differentials and airway hyperresponsiveness (AHR). $\mathbf{d}$. Western blot analysis of lung cell extracts from sham- or acrolein-treated mice. Moesin expression in lung cells from OVA plus acrolein-treated mice was higher than in lung cells from sham-treated mice. e. lung tissues from acrolein-treated and sham-treated mice were incubated with biotinylated anti-goat Moesin antibody (1100 dilution). Moesin was detected using an avidin-biotin peroxidase complex kit and staining with 3,3'-diaminobenzidine tetrachloride (Zymed Laboratories Inc.) with hematoxylin as a counterstain. Moesin protein expression was notably higher in the lung endothelial cells and epithelial cells from acrolein-treated mice than in that from sham-treated mice

And acrolein $30 \mathrm{nM}$ altered 11 proteins including antioxidant, signal transduction, cytoskeleton, protein transduction, catalytic reduction such as CAP, ANXA5, YWHAE), PLA2, eIF-4D, fibrin beta, TPM2, VIM, GST- $\pi$, and GAPDH. Acrolein $300 \mathrm{nM}$ altered 10 protein spots such as ANXA1, HSP7C, TPM4, YWHAE, ANXA5, Moesin, isoform CRA_b, GAPDH, and GRP78. Further studies will be needed for different expression pattern by different acrolein concentration.

Tropomyosin (TPM) is a component of the muscle sarcomeric thin filament where it plays a central role in the calcium-dependent regulation of striated muscle contraction. TPM exists as a rod-shaped dimer that forms a head-to-tail polymer along the length of an actin filament providing stability and it is essential for myosin- 
actin interaction [42-45]. Annexins are a family of 13 structurally related, Ca-dependent, phospholipid binding proteins [46] that modulate numerous physiological and pathological processes, including anticoagulation, antiinflammation, cell migration, proliferation, apoptosis, and membrane-trafficking activities [47-50]. Ezrin/Radixin/ Moesin (ERM) proteins are important actin-binding molecules that are targets for threonine phosphorylation in various signal pathways to induce actin remodelling and control vascular permeability $[51,52]$.

Of the 21 proteins we identified, we selected moesin for validation for airway inflammation in a mouse model of asthma. We found that moesin protein expression was increased in acrolein treated mice as compared with sham mice (Fig. 5). This result agrees with our results from 2-D electrophoresis, suggest that moesin can be an important role as a marker of airway inflammation. The immunopathogenesis of the acrolein model of airway inflammation has been considered to be quite different from that of the ovalbumin-challenged model. To our knowledge, our results provide the first clear demonstration that moesin in endothelial cells is induced by acrolein, suggesting that moesin have an important role for airway responsiveness and airway inflammation.

\section{Conclusion}

The authors identified 21 proteins whose expression levels in the HMVEC-L cell line changed in response to acrolein exposure. These proteins include antioxidant, signal transduction, cytoskeleton, protein transduction, catalytic reduction implicated in the response to oxidative stress, and they can be classified into four groups according to the pattern of their acrolein-induced change in expression over time. One of these proteins, expression of moesin protein was increased in the lungs of acrolein-treated mice. These results indicate that some of these proteins may serve as mediators of, or markers for, airway disease caused by exposure to acrolein.

\section{Additional file}

Additional file 1: Figure S1. A. Western blot analysis of lung protein extracts from sham- or acrolein-treated mice. Annexin A1 and Tropomyosin 2 expression in OVA plus acrolein-treated mice was higher than in shamtreated mice. B. lung tissues from acrolein-treated and sham-treated mice were incubated with biotinylated anti-rabbit Annexin A1 and Tropomyosin 2 antibody (1:500 dilution). Annexin A1 and Tropomyosin was detected using an avidin-biotin peroxidase complex kit and staining with 3,3'diaminobenzidine tetrachloride (Zymed Laboratories Inc.) with hematoxylin as a counterstain. Annexin A1 and Tropomyosin 2 protein expression was higher in acrolein-treated mice than in that from sham-treated mice. (DOCX $1404 \mathrm{~kb}$ )

\section{Abbreviations}

2-DE: Two-dimensional electrophoresis; ACN: Acetonitrile; BALF: Bronchoalveolar lavage fluid; COPD: Chronic Obstructive Pulmonary Disease; HMVEC-L: Human Microvascular Endothelial Cells-Lung; MALDI-TOF
MS: Matrix-assisted laser desorption/ionization time-of-flight mass spectrometry

\section{Acknowledgements}

This research was supported by a grant of the Korea Health Technology R\&D Project through the Korea Health Industry Development Institute (KHIDI).

\section{Funding}

This work was supported by the Ministry of Health \& Welfare, Republic of Korea (grant number: HI15C2032) and Soonchunhyang University Research Fund.

Availability of data and materials

All the data generated or analyzed during this study are included in this published article.

\section{Authors' contributions}

AS designed the study and draft the manuscript; GD coordinated the study, and assisted with the writing of the manuscript. PH participated in analyzed data and carried out MS analysis and performed protein identification. BG and $\mathrm{SH}$ carried out the animal experiments. All authors read and approved the final manuscript.

Ethics approval and consent to participate

This study was performed in accordance with the Institutional Animal Care and Use Committee of the Soonchunhang University Bucheon Hospital

Consent for publication

Not applicable

Competing interests

The authors declare that they have no competing interests.

\section{Publisher's Note}

Springer Nature remains neutral with regard to jurisdictional claims in published maps and institutional affiliations.

\section{Author details}

${ }^{1}$ Division of Allergy and Respiratory Medicine, Department of Internal Medicine, Soonchunhyang University Bucheon Hospital, 170 Jomaru-ro, Wonmi-gu, Bucheon, Gyeonggi-do 420-767, South Korea. 'Department of Environmental and Occupational Health, Graduate School of Public Health, University of Pittsburgh, Pittsburgh, PA, USA.

Received: 31 July 2017 Accepted: 22 December 2017

Published online: 17 January 2018

\section{References}

1. Piipari R, Jaakkola JJK, Jaakkola N, Jaakkola MS. Smoking and asthma in adults. Eur Respir J. 2004:24:734-9.

2. Jang AS, Park JS, Lee JH, Park SW, Kim DJ, ST U, Kim YH, Park CS. The impact of smoking on clinical and therapeutic effects in asthmatics. J Korean Med Sci. 2009;24:209-14.

3. Thomson NC, Spears M. The influence of smoking on the treatment response in patients with asthma. Curr Opin Allergy Clin Immunol. 2005;5:57-63.

4. UK Gov. Living in Britain: results from the 2002 General Household Survey. Office for National Statistics. 2004;Available at http://www.statistics.gov.uk/ lib.

5. Lange P, Parner J, Vestbo J, Schnohr P, Jensen G. A 15 year followup study of ventilatory function in adults with asthma. N Engl J Med. 1998;339:1194-200.

6. Marquette $\mathrm{CH}$, Saulnier F, Leroy O, Wallaert B, Chopin C, Demarcq JM, Durocher A, Tonnel AB. Long-term prognosis of near-fatal asthma. A 6-year follow-up study of 145 asthmatic patients who underwent mechanical ventilation for a near-fatal attack of asthma. Am Rev Respir Dis. 1992;146:76-81.

7. Jang AS, Kim SH, Kim TB, Park HW, Kim SH, Chang YS, Lee JH, Cho YS, Park JW, Nahm DH, Cho YJ, Cho SH, Yoon HJ, Choi BW, Moon HB, Park CS. COREA study group. Impact of atopy on asthma and allergic rhinitis in the cohort for reality and evolution of adult asthma in Korea. Allergy Asthma Immunol Res. 2013;5:143-9.

8. Jang AS, Park SW, Kim DJ, Uh S, Kim YH, Whang HG, Lim Gl, Park CS. Effects of smoking cessation on airflow obstruction and quality of life in asthmatic smokers. Allergy Asthma Immunol Res. 2010;2:254-9. 
9. Harkness LM, Ashton AW, Burgess JK. Asthma is not only an airway disease, but also a vascular disease. Pharmacol Ther. 2015;148:17-33.

10. Potente M, Gerhardt H, Carmeliet P. Basic and therapeutic aspects of angiogenesis. Cell. 2011;146:873-87.

11. Ausprunk DH, Folkman J. Migration and proliferation of endothelial cells in preformed and newly formed blood vessels during tumor angiogenesis. Microvasc Res. 1977;14:53-65.

12. Sumpio BE, Riley JT, Dardik A. Cells in focus: endotelial cell. Int J Biochem Cell Biol. 2002;34:1508-12.

13. Ait-Oufella H, Maury E, Lehoux S, Guidet B, Offenstadt G. The endothelium: physiological functions and role in microcirculatory failure during severe sepsis. Intensive Care Med. 2010;36:1286-98.

14. Schnaper HW, Kleinman HK, Grant DS. Role of laminin in endothelial cell recognition and differentiation. Kidney Int. 1993;43:20-5.

15. Folkman J, Shing Y. Angiogenesis. J Biol Chem. 1992;267(16):10931-4.

16. Schmid MC, Varner JÁ. Myeloid cells in the tumor microenvironment: modulation of tumor angiogenesis and tumor inflammation. J Oncol. 2010; 2010:201026.

17. Zayed MA, Yuan W, Chalothorn D, Faber JE, Parise LV. Tumor growth and angiogenesis is impaired in CIB1 knockout mice. J Angiogenes Res. 2010;2: 17-24.

18. Guvakova MA. Insulin-like growth factors control cell migration in health and disease. Int J Biochem Cell Biol. 2007;39:890-909.

19. Bein K, Leikauf GD. Acrolein - a pulmonary hazard. Mol Nutr Food Res. 2011;55:1342-60.

20. Ho SS, JZ Y, Chu KW, Yeung LL. Carbonyl emissions from commercial cooking sources in Hong Kong. J Air Waste Manag Assoc. 2006;56(8):1091-8.

21. Spada N, Fujii E, Cahill TM. Diurnal cycles of acrolein and other small aldehydes in regions impacted by vehicle emissions. Environ Sci Technol. 2008;42:7084-90.

22. Nazaroff WW, Singer BC. Inhalation of hazardous air pollutants from environmental tobacco smoke in US residences. J Expo Anal Environ Epidemiol. 2004;14:S71-7.

23. Siegel M. Involuntary smoking in the restaurant workplace. A review of employee exposure and health effects. J Am Med Assoc. 1993;270:490-3.

24. Reijula JP, Reijula KE. The impact of Finnish tobacco legislation on restaurant workers' exposure to tobacco smoke at work. Scand J Public Health. 2010; 38(7):724-30.

25. Corradi M, Pignatti P, Manini P, Andreoli R, Goldoni M, Poppa M, Moscato G, Balbi B, Mutti A. Comparison between exhaled and sputum oxidative stress biomarkers in chronic airway inflammation. Eur Respir J. 2004:24:1011-7.

26. Sarkar $P$, Hayes BE. Proteomic profiling of rat lung epithelial cells induced by acrolein. Life Sci. 2009:85:188-95.

27. Spiess PC, Deng B, Hondal RJ, Matthews DE, van der Vliet A. Proteomic profiling of acrolein adducts in human lung epithelial cells. J Proteome. 2011;74:2380-94.

28. Borchers MT, Wesselkamper S, Wert SE, Shapiro SD, Leikauf GD. Monocyte inflammation augments acrolein-induced muc5ac expression in mouse lung. Am J Phys. 1999;277(3 Pt 1):L489-97.

29. Cha MH, Rhim T, Kim KH, Jang AS, Paik YK, Park CS. Proteomic identification of macrophage migration-inhibitory factor upon exposure to $\mathrm{TiO} 2$ particles. Mol Cell Proteomics. 2007;6:56-63.

30. Harkness LM, Kanabar V, Sharma HS, Westergren-Thorsson G, LarssonCallerfelt AK. Pulmonary vascular changes in asthma and COPD. Pulm Pharmacol Ther. 2014;29:144-55.

31. Postma DS, Timens W. Remodeling in asthma and chronic obstructive pulmonary disease. Proc Am Thorac Soc. 2006;3:434-9.

32. Doherty T, Broide D. Cytokines and growth factors in airway remodeling in asthma. Curr Opin Immunol. 2007;19:676-80.

33. Alagappan VK, de Boer WI, Misra VK, Mooi WJ, Sharma HS. Angiogenesis and vascular remodeling in chronic airway diseases. Cell Biochem Biophys. 2013:67:219-34

34. Carroll NG, Cooke C, James AL. Bronchial blood vessel dimensions in asthma. Am J Respir Crit Care Med. 1997;155:689-95.

35. Vrugt B, Wilson S, Bron A, Holgate ST, Djukanovic R, Aalbers R. Bronchial angiogenesis in severe glucocorticoid-dependent asthma. Eur Respir J. 2000; 15:1014-21.

36. Salvato G. Quantitative and morphological analysis of the vascular bed in bronchial biopsy specimens from asthmatic and non-asthmatic subjects. Thorax. 2001;56:902-6.
37. Logue JM, Small MJ, Stern D, Maranche J, Robinson AL. Spatial variation in ambient air toxics concentrations and health risks between industrialinfluenced, urban, and rural sites. J Air Waste Manag Assoc. 2010;60:271-86.

38. Stevens JF, Maier CS. Acrolein: sources, metabolism, and biomolecular interactions relevant to human health and disease. Mol Nutr Food Res. 2008;52:7-25.

39. Moretto N, Volpi G, Pastore F, Facchinetti F. Acrolein effects in pulmonary cells: relevance to chronic obstructive pulmonary disease. Ann N Y Acad Sci. 2012;1259:39-46

40. Weber A, Jermini C, Grandjean E. Irritating effects onman of air pollution due to cigarette smoke. Am J Public Health. 1976;66:672-6.

41. Deshmukh HS, Shaver C, Case LM, Dietsch M, Wesselkamper SC, Hardie WD, Korfhagen TR, Corradi M, Nadel JA, Borchers MT, Leikauf GD. Acroleinactivated matrix metalloproteinase 9 contributes to persistent mucin production. Am J Respir Cell Mol Biol. 2008:38:446-54.

42. Abdul-Hussein S, Rahl K, Moslemi AR, Tajsharghi H. Phenotypes of myopathy-related beta-tropomyosin mutants in human and mouse tissue cultures. PLoS One. 2013;8:e72396.

43. Gordon AM, Homsher $\mathrm{E}$, Regnier M. Regulation of contraction in striated muscle. Physiol Rev. 2000;80(2):853-924.

44. Perry SV. Vertebrate tropomyosin: distribution, properties and function. J Muscle Res Cell Motil. 2001;22:5-49.

45. Quax W, Meera Khan P, Quax-Jeuken Y, Bloemendal H. The human desmin and vimentin genes are located on different chromosomes. Gene. 1985;38:189-96.

46. Gerke V, Moss SE. Annexins: from structure to function. Physiol Rev. 2002:82:331-71.

47. Chen Z, Yoshihara E, Son A, Matsuo Y, Masutani H, Sugie K, Maeda M, Yodoi J. Differential roles of Annexin A1 (ANXA1/lipocortin-1/lipomodulin) and thioredoxin binding protein-2 (TBP-2NDUP1/TXNIP) in glucocorticoid signaling of HTLV-I-transformed T cells. Immunol Lett. 2010;31:11-8.

48. Mirnikjoo B, Balasubramanian K, Schroit AJ. Suicidal membrane repair regulates phosphatidylserine externalization during apoptosis. J Biol Chem. 2009:284:22512-6.

49. Luo C, Ji X, Fan J, Hou Z, Wang T, Wu B, Ni C. Annexin A5 promotes macrophage activation and contributes to pulmonary fibrosis induced by silica particles. Toxicol Ind Health. 2016;32(9):1628-38

50. Parente L, Solito E. Annexin 1: more than an anti-phospholipase protein Inflamm Res. 2004;53:125-32.

51. García-Ponce A, Citalán-Madrid AF, Velázquez-Avila M, Vargas-Robles H, Schnoor M. The role of actin-binding proteins in the control of endothelial barrier integrity. Thromb Haemost. 2015;113:20-36.

52. Koss M, Pfeiffer GR, Wang Y, Thomas ST, Yerukhimovich M, Gaarde WA, Doerschuk CM, Wang Q. Ezrin/radixin/moesin proteins are phosphorylated by TNF-alpha and modulate permeability increases in human pulmonary microvascular endothelial cells. J Immunol. 2006;176:1218-27.

\section{Submit your next manuscript to BioMed Central and we will help you at every step:}

- We accept pre-submission inquiries

- Our selector tool helps you to find the most relevant journal

- We provide round the clock customer support

- Convenient online submission

- Thorough peer review

- Inclusion in PubMed and all major indexing services

- Maximum visibility for your research

Submit your manuscript at www.biomedcentral.com/submit 